\title{
INFLUENCE OF DATA ACQUISITION GEOMETRY ON SOYBEAN SPECTRAL RESPONSE SIMULATED BY THE PROSAIL MODEL ${ }^{1}$
}

\author{
FÁBIO M. BREUNIG ${ }^{2}$, LÊNIO S. GALVÃO ${ }^{3}$, ANTONIO R. FORMAGGIO ${ }^{4}$, \\ JOSÉ C. N. EPIPHANIO
}

\begin{abstract}
View angle and directional effects significantly affect reflectance and vegetation indices, especially when daily images collected by large field-of-view (FOV) sensors like the Moderate Resolution Imaging Spectroradiometer (MODIS) are used. In this study, the PROSAIL radiative transfer model was chosen to evaluate the impact of the geometry of data acquisition on soybean reflectance and two vegetation indices (Normalized Difference Vegetation Index - NDVI and Enhanced Vegetation Index - EVI) by varying biochemical and biophysical parameters of the crop. Input values for PROSAIL simulation were based on the literature and were adjusted by the comparison between simulated and real satellite soybean spectra acquired by the MODIS/Terra and hyperspectral Hyperion/Earth Observing-One (EO-1). Results showed that the influence of the view angle and view direction on reflectance was stronger with decreasing leaf area index (LAI) and chlorophyll concentration. Because of the greater dependence on the near-infrared reflectance, the EVI was much more sensitive to viewing geometry than NDVI presenting larger values in the backscattering direction. The contrary was observed for NDVI in the forward scattering direction. In relation to the LAI, NDVI was much more isotropic for closed soybean canopies than for incomplete canopies and a contrary behavior was verified for EVI.
\end{abstract}

KEYWORDS: leaf area index, NDVI, EVI, reflectance, MODIS, remote sensing.

\section{INFLUÊNCIA DA GEOMETRIA DE AQUISIÇÃO DE DADOS NA RESPOSTA ESPECTRAL DA SOJA SIMULADA PELO MODELO PROSAIL}

RESUMO: Os efeitos direcionais e de ângulo de visada afetam significativamente a reflectância e os índices de vegetação, especialmente quando são usadas imagens diárias adquiridas por sensores com amplo campo de visada como o Moderate Resolution Imaging Spectroradiometer (MODIS). No presente estudo, o modelo de transferência radiativa PROSAIL foi escolhido para avaliar o impacto da geometria de aquisição de dados na reflectância da soja e no cálculo de dois índices de vegetação (Normalized Difference Vegetation Index - NDVI e Enhanced Vegetation Index - EVI), variando-se parâmetros bioquímicos e biofísicos do dossel. Os valores usados para a simulação PROSAIL foram definidos com base na literatura e foram ajustados pela comparação entre espectros de soja simulados e adquiridos pelos sensores MODIS/Terra e hiperespectral Hyperion/Earth Observing-One (EO-1). Os resultados mostraram que os efeitos direcionais e de ângulo de visada na reflectância foram mais fortes com a diminuição do índice de área foliar (IAF) e da concentração de clorofila. Por ser mais dependente da banda do infravermelho próximo (IVP), o EVI foi muito mais sensível à geometria de visada do que o NDVI, apresentando maiores valores na direção do retroespalhamento. O contrário foi observado para o NDVI na direção do espalhamento frontal. Em relação ao IAF, o NDVI foi mais isotrópico para dosséis fechados de soja do que para dosséis esparsos, e um comportamento contrário foi verificado para o EVI.

PALAVRAS-CHAVE: índice de área foliar, NDVI, EVI, reflectância, MODIS, sensoriamento remoto.

\footnotetext{
${ }^{1}$ Partially funded by FAPESP, CNPq and CAPES.

${ }^{2}$ Professor Adjunto, Universidade Federal de Santa Maria (UFSM).

${ }^{3}$ Pesquisador Titular, Instituto Nacional de Pesquisas Espaciais (INPE).

${ }^{4}$ Pesquisador Titular, Instituto Nacional de Pesquisas Espaciais (INPE).

${ }^{5}$ Pesquisador Titular, Instituto Nacional de Pesquisas Espaciais (INPE).

Recebido pelo Conselho Editorial em: 5-3-2012

Aprovado pelo Conselho Editorial em: 3-9-2012
} 


\section{INTRODUCTION}

Soybean is one of the worldwide most important agricultural commodities. Brazil is an important soybean producer and has presented an expressive increase in planted area in the last decades. The adequate monitoring of the Brazilian soybean planted areas is usually expensive and time-consuming when performed through intensive field inspection. Remote sensing, based on the use of satellite images acquired by large swath-width sensors, like the Moderate Resolution Imaging Spectroradiometer (MODIS), is cost-effective for an adequate temporal monitoring of soybean development and crop production (RIZZI \& RUDORFF, 2007; WARDLOW \& EGBERT, 2008; RODRIGUEZ et al., 2009; MARSDEN et al., 2010; ARAUJO et al., 2011).

MODIS is onboard the Terra and Aqua satellites launched in 1999 and 2002, respectively. Its cross-track scanning radiometer has a field-of-view (FOV) of $110^{\circ}$ ( $\pm 55^{\circ}$ from nadir) with a resultant swath width of $2,300 \mathrm{~km}$. It operates in both platforms from an altitude of $705 \mathrm{~km}$, covering the spectral region from 0.4 to $14.5 \mu \mathrm{m}$ in 36 bands with variable spatial resolution of $250 \mathrm{~m}$ (bands 1-2), $500 \mathrm{~m}$ (3-7) and 1,000 m (bands 8-36) (XIONG et al., 2009). As a function of its large swath width, MODIS has a continuous and near global coverage of 1 to 2 days, which increases the probability of acquiring cloud-free images in central Brazil just at peak of soybean development (January to February). On the other hand, because of the large swath width, the same soybean field can be sensed by MODIS in close dates with different view angles and directions (backscattering and forward scattering). Due to the anisotropy of the vegetation, soybean fields with the same biochemical and biophysical attributes can present very different spectral reflectance solely due to changes in the geometry of data acquisition (GALVÃ̃ et al., 2009). Even the 8- or 16-day MODIS composite products of surface reflectance or vegetation indices can show large variation in quality and reliability due to infrequent observations resultant from cloud cover, which precludes adequate view angle constraints for pixel selection.

Besides the high temporal resolution, an important contribution provided by the off-nadir viewing is the generation of biophysical image products. MODIS data acquired at variable viewillumination geometries describe the vegetation anisotropy and provide inputs for the inversion of the 3D radiative transfer models to estimate biophysical parameters such as the leaf area index (LAI). LAI can be related to crop production and yield (FANG et al., 2008). However, atmospheric contamination may limit the number of input images necessary for inversion. In this case, LAI is generally estimated from available empirical relationships between LAI and NDVI through a Backup Algorithm (BREUNIG et al., 2011).

Despite the fact that most of the MODIS products have an associated pixel quality assurance information, the majority of the users do not consider pixel retrieval quality (e.g., atmospheric or view angle effects) on their studies. In fact, the magnitude of the view-illumination effects on crop spectral response has not received great attention in the literature. Thus, a better comprehension of the impact of the geometry of data acquisition on reflectance and vegetation indices of crops is still necessary to avoid misinterpretation of MODIS data.

Radiative transfer modeling can be used for this purpose. The integration of the leaf radiative transfer PROSPECT (FÉRET et al., 2008) with the canopy radiative transfer SAIL (Scattering by Arbitrarily Inclined Leaves) (VERHOEF, 1984; VERHOEF et al., 2007) generated a complete leafcanopy model named PROSAIL (JACQUEMOUD et al., 2009). PROSAIL model allows varying combinations of data regarding the following input parameters: pigment concentration, leaf and canopy structure parameters (Leaf Inclination Distribution Function - LIDF, LAI), atmosphere conditions and view-illumination geometry (Solar Zenith Angle - SZA; View Zenith Angle - VZA; and Relative Azimuth Angle - RAA).

Considering the hypothesis that MODIS off-nadir data can significantly introduce spectral variability for soybean fields, the objective of this study was to evaluate the impact of the geometry of data acquisition on soybean reflectance and vegetation indices. For this purpose, it was used the PROSAIL radiative transfer algorithm to simulate the soybean spectral response by varying data 
acquisition geometry (VZA) and biochemical (e.g., chlorophyll) and biophysical (e.g., LAI and LIDF) parameters.

\section{PROSAIL}

Biophysical and biochemical parameters of the canopy can be estimated by the inversion of empirical-statistical methods or physically-based radiative transfer models such as PROSAIL (ATZBERGER, 2010). Radiative transfer models are valuable tools to improve the interpretation of remote sensing products and to formulate new methods for retrieving biophysical and biochemical properties. The coupled leaf-canopy PROSAIL model (PROSPECT + SAIL) is widely used for planning new sensors capability, to improve and test vegetation indices, and to better understand radiation regime within vegetation stands (JACQUEMOUD et al., 2009). Several improvements were implemented and are continually being developed aiming to represent increasingly better the actual radiation propagation at leaf and canopy levels.

At leaf scale, PROSPECT was derived from the Allen's generalized plate model and currently allows as input the chlorophyll concentration $(\mathrm{Cab})$, carotenoid concentration (Car), equivalent water thickness $(\mathrm{Cw})$, dry matter content $(\mathrm{Cm})$, and the leaf mesophyll structure parameter $(\mathrm{N}$, angiosperm or gymnosperm). To simulate the leaf directional-hemispherical reflectance and transmittance, the model uses look-up-tables with the specific absorption coefficients and refractive index of leaf components (FÉRET et al., 2008).

At canopy scale, SAIL is a widespread accepted canopy radiative transfer model initially proposed by VERHOEF (1984) to simulate the bidirectional reflectance factor (BRF) considering distinct sun and view geometry angles. Data acquisition geometry parameters can significantly change the reflectance if one considers using off-nadir data (BREUNIG et al., 2011). Plant biophysical parameters, such as LAI and LIDF, are used to represent crop phenology on the BRF. Hot spot parameter is usually set to 0.2 since this value represent nearly the actual effect of this phenomena on the BRF. Biochemical parameters (e.g., chlorophyll $a$ and $b-C_{a b}$ ) change the

reflectance in the visible spectral range with maximum absorption in the blue and red bands. Carotenoids have more influence close to the senescence stage with decreasing chlorophyll content. Structural parameters (e.g., LAI and LIDF) determine the radiation regime within the canopy according to the plant architecture, crop development and calendar, management and regional aspects (GALVÃO et al., 2011a).

\section{MATERIAL AND METHODS}

\section{Definition of the PROSAIL input data}

In order to define the PROSAIL input parameters, several tests were carried out and the literature was used. A summary of the model input values is presented in Table 1. Leaf structure parameter and $C_{a b}$ were set according to FRITSCHI \& RAY (2007) and WANG et al. (2011). The other biochemical parameters were set according to preliminary evaluations, based on the PROSAIL look-up-table (LUT) provided by FÉRET et al. (2008). The structural parameter $N$ was defined for a dicotyledonous plant (soybean) characterized by a spongy parenchyma with air cavities (JACQUEMOUD, 1993).

To represent the soybean planophile canopy architecture, an average leaf inclination distribution function (LIDF) value of $13^{\circ}$ was first defined based on the WinSAIL implemented algorithm for soybean crops. Soil reflectance was extracted from a topsoil reflectance spectrum acquired in the Brazilian Mato Grosso State by the Airborne Visible/Infrared Imaging Spectrometer (AVIRIS) over dry dystrophic Red Latosol (Rhodic Acrustox in the Soil Taxonomy), a common soil type in soybean farms of central Brazil. After preliminary tests, the hot spot parameter was set to 0.2 . Ratio of diffuse to total incident radiation was set to $20 \%$, which corresponds to a visibility of $50 \mathrm{~km}$, typical for a cloudless atmosphere (JACQUEMOUD, 1993). 
TABLE 1. Main parameters used as input for PROSAIL (PROSPECT + SAIL) simulations.

\begin{tabular}{|c|c|c|c|c|}
\hline Model & Symbol & Quantity & Range (step) & Unit \\
\hline \multirow{6}{*}{ 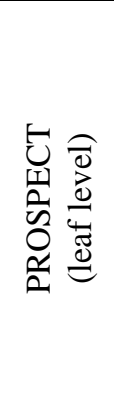 } & $C_{a b}$ & Chlorophyll $\mathrm{a}+\mathrm{b}$ content & $10-60(10)$ & $\mu \mathrm{g} \mathrm{cm}^{-2}$ \\
\hline & $C_{c c}$ & Carotenoid content & 13 & $\mu \mathrm{g} \mathrm{cm}^{-2}$ \\
\hline & $C_{w}$ & Equivalent water thickness & 0.02 & $\mathrm{~cm}$ \\
\hline & $C_{m}$ & Dry matter content & 0.009 & $\mathrm{~g} \mathrm{~cm}^{-2}$ \\
\hline & $C_{b p}$ & Brown pigments content & 0.3 & - \\
\hline & $N$ & Leaf structure parameter & $1.5 \mathrm{~N}$ & - \\
\hline \multirow{5}{*}{ 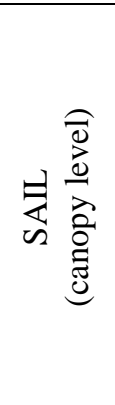 } & $\begin{array}{l}\text { LAI } \\
\text { LIDF }\end{array}$ & $\begin{array}{l}\text { Leaf area index } \\
\text { Leaf inclination distribution function }\end{array}$ & $\begin{array}{l}0.01 \text { to } 7(1) \\
10 \text { to } 75(5)\end{array}$ & $\begin{array}{c}- \\
\text { Degree }\end{array}$ \\
\hline & $S_{L}$ & Hot spot parameter & 0.2 & $\mathrm{~mm}^{-1}$ \\
\hline & $\rho_{s}$ & Soil reflectance assumed Lambertian or not & 1 & - \\
\hline & $\begin{array}{l}\text { SKYL } \\
\text { SZA } \\
\text { VZA }\end{array}$ & $\begin{array}{l}\text { Ratio of diffuse to total incident radiation } \\
\text { Solar zenith angle } \\
\text { Viewing zenith angle }\end{array}$ & $\begin{array}{c}20 \\
30 \\
-45 \text { to } 45(5)\end{array}$ & $\begin{array}{c}\% \\
\text { Degree } \\
\text { Degree }\end{array}$ \\
\hline & RAA & Relative azimuth angle & 0 & Degree \\
\hline
\end{tabular}

To evaluate the ability of PROSAIL to reproduce real spectra of soybean fields, we compared the PROSAIL simulated spectra with real soybean spectra derived from the Hyperion/Earth Observing One (EO-1) hyperspectral satellite sensor and from the MODIS/Terra multispectral sensor. PROSAIL simulations were performed using the same Hyperion and MODIS geometry of data acquisition with a LAI of 5. The images were acquired over a soybean farm located in Querência municipality (State of Mato Grosso, Brazil). The Hyperion image was obtained with offnadir viewing $\left(-21.5^{\circ}\right)$ in the forward scattering direction on February 8, 2005. Two MODIS images were obtained on February 5 and 6, 2005, in opposite directions (backscattering at $42^{\circ}$ VZA and forward scattering at $-44^{\circ}$ VZA, respectively). A brief description of the Hyperion and MODIS images and of the soybean farm for this study is found in GALVÃO et al. (2011a,b) and BREUNIG et al. (2011).

\section{Data analysis}

Viewing configuration was changed to perform several representations of VZA $\left( \pm 45^{\circ}\right.$ from nadir) for different chlorophyll concentrations (10 to $\left.60 \mu \mathrm{g} \mathrm{cm}^{-2}\right)$, LAI $(0.01$ to 7$)$ and LIDF (10 ${ }^{\circ}$ to $75^{\circ}$ ) values (Table 1). The resultant PROSAIL reflectance spectra $(400-2500 \mathrm{~nm})$ were analyzed. All the simulations were performed using the Matlab® environment (The MathWorks Inc. 2008). Because SZA does not vary too much during the peak of soybean development in central Brazil (January to February), we kept this parameter fixed at $30^{\circ}$ (SZA). The RAA was also fixed at $0^{\circ}$ (principal plane of scattering). Thus, results were evaluated by keeping several PROSAIL input parameters constant while varying others (VZA, LIDF and chlorophyll). In this study, negative VZA indicates the forward scattering (predominance of shadowed canopies for the sensor), whereas positive VZA represents the backscattering (predominance of sunlit canopies).

Different plots were elaborated representing the view angle-directional effects resultant from changes in chlorophyll, LAI and LIDF on the reflectance and two vegetation indices (Normalized Difference Vegetation Index - NDVI; and Enhanced Vegetation Index - EVI). NDVI and EVI, which are the two indices used in MODIS vegetation index composite products, were calculated using Equations 1 and 2, considering the central wavelength of the Hyperion narrow bands:

$$
N D V I=\left(\rho_{864}-\rho_{671}\right) /\left(\rho_{864}+\rho_{671}\right)
$$




$$
E V I=G *\left(\frac{\rho_{864}-\rho_{671}}{\rho_{864}+C_{1} * \rho_{671}-C_{2} * \rho_{467}+L}\right)
$$

where,

$\rho_{x}$ - simulated and the atmospherically corrected surface reflectance;

$L$ - canopy background adjustment (we adopted $L=1$ );

$C_{1} ; C_{2}$ - coefficients of the aerosol resistance term $\left(C_{1}=6, C_{2}=7.5\right)$;

$G$ - scaling factor $(G=2.5)$ (SOLANO et al., 2010).

To allow comparisons between results from a common baseline, we calculated the anisotropic reflectance factor (ANIF), which comprises simulated off-nadir data normalization (reflectance) to nadir viewing (SANDMEIER \& ITTEN, 1999). The same strategy was adopted for NDVI and EVI, which were also normalized to nadir viewing.

\section{RESULTS}

\section{PROSAIL simulated versus real satellite soybean spectra}

An overall good agreement was verified in the red edge, near infrared (NIR) and shortwave infrared (SWIR) spectral regions between real and PROSAIL simulated soybean reflectance spectra for Hyperion/EO-1 (Figure 1a) and MODIS/Terra (Figure 1b). However, the greatest differences for Hyperion were observed in the visible interval and were probably associated with atmospheric scattering effects. For MODIS, simulated PROSAIL reflectance curves, when compared to real spectra, displayed lower values in the entire 400-2500 nm range.

Despite the differences between real and simulated reflectance spectra mainly observed for MODIS, results of Figure 1 confirmed the good performance of PROSAIL to represent the soybean spectral reflectance using the input parameters of Table 1.

(a)

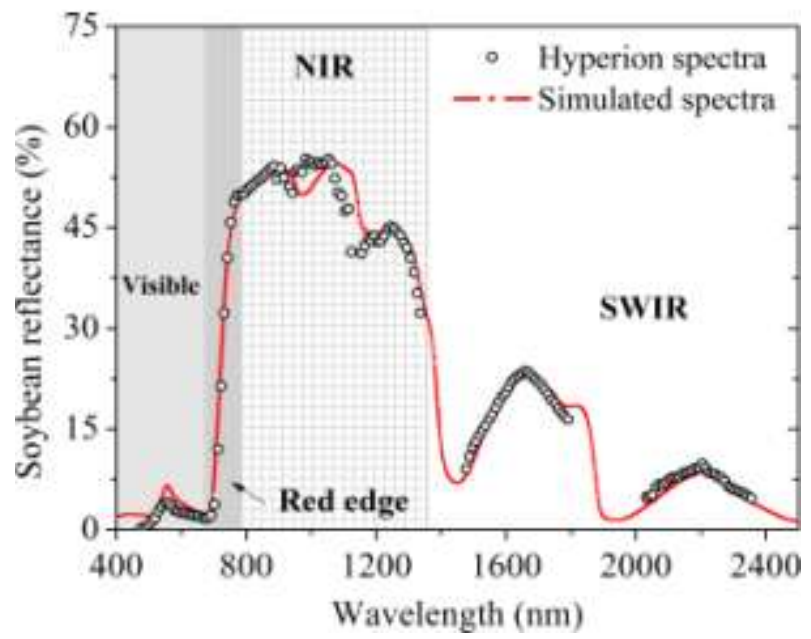

(b)

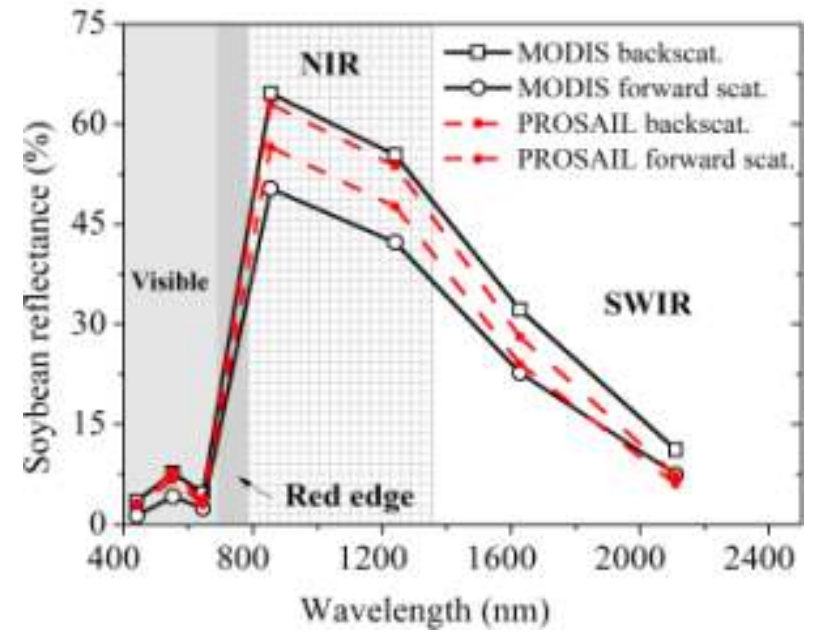

FIGURE 1. Comparison of simulated PROSAIL spectra with real spectra measured by a) Hyperion/EO-1 on February 8, 2005 (forward scattering), and b) MODIS/Terra on February 5, 2005 (backscattering) and on February 6, 2005 (forward scattering).

\section{Variation in biochemical and biophysical parameters: the soybean reflectance anisotropy from PROSAIL}

PROSAIL results showed that the soybean variations in chlorophyll $a$ and $b$ concentration changed the red reflectance at $661 \mathrm{~nm}$, which varied with VZA for distinct LAI values (2 and 5), especially at the hot spot position (SZA and VZA $=30^{\circ}$ in Figure 2). The red reflectance decreased as the chlorophyll concentration increased, because of the more radiation absorption in the visible 
due to the photosynthesis (Figure 2a). Similar results were obtained in the blue wavelength region, as expected (results not shown). View angle effects on reflectance were stronger in the backscattering (positive view angles) than in forward scattering direction (negative view angles) due to the hot spot effects. ANIF results (normalized to nadir) indicated that view angle and directional effects were reduced when chlorophyll content increased from 10 to $60 \mu \mathrm{g} \mathrm{cm}^{-2}$ (Figure $2 b)$. The magnitude of angular effects decreased also significantly with canopy closure, as deduced from the comparison between Figures $2 b(\mathrm{LAI}=2)$ and $2 \mathrm{c}(\mathrm{LAI}=5)$. For closed soybean canopies $(\mathrm{LAI}=5)$, changes in VZA produced much smaller reflectance variations for different chlorophyll concentrations when compared to incomplete canopies $(\mathrm{LAI}=2)$. Thus, in time series analysis of satellite data of annual crops like soybean, the magnitude of the directional effects, in the visible interval, decreases with crop development or reproductive stages.
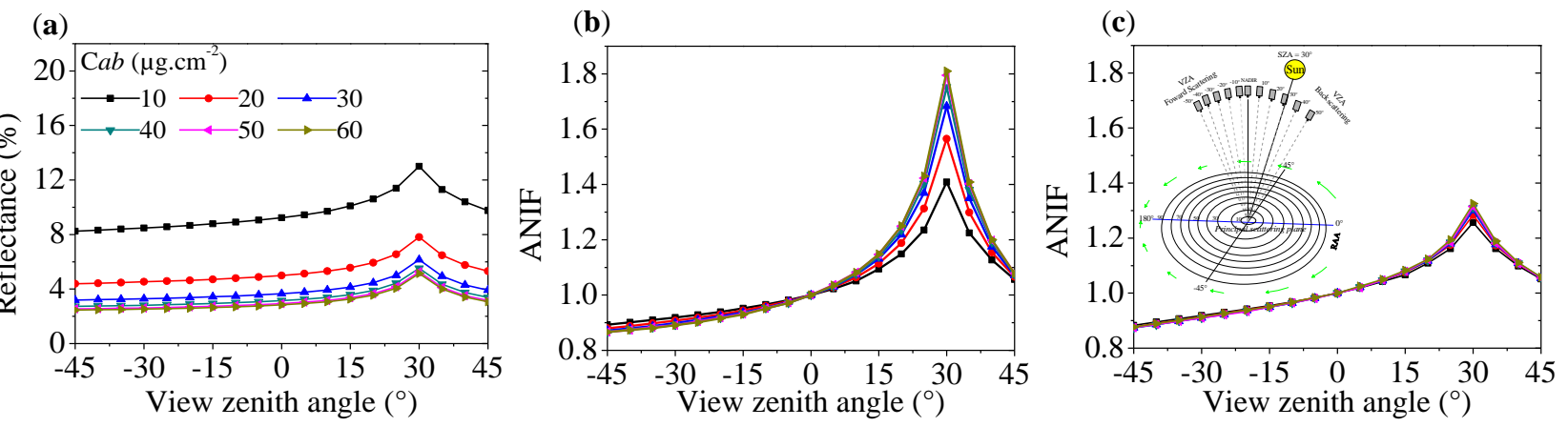

FIGURE 2. Directional and view zenith angle (VZA) effects, as a function of different concentrations of chlorophyll $a$ and $b$, on the a) red reflectance $(660 \mathrm{~nm})$ of soybean for LAI 2; b) red anisotropic reflectance factor (ANIF) for LAI 2, and c) red ANIF for LAI 5. SZA $\left(30^{\circ}\right)$, RAA $\left(0^{\circ}\right)$, LIDF $\left(13^{\circ}\right)$ and other parameters of Table 1 were kept fixed.

The main biophysical parameters that affect reflectance are LAI and LIDF. For a constant chlorophyll concentration $\left(30 \mu \mathrm{g} \mathrm{cm}^{-2}\right)$, an increase in LAI produced light absorption in the visible (Figure 3a) and multiple scattering of radiation in the NIR (results not shown). View angle effects on red reflectance were stronger in the backscattering and at the hot spot $\left(30^{\circ} \mathrm{VZA}\right)$, and decreased with increasing LAI (Figure 3b). For LAI higher than 5, no significant changes were observed in the red interval due to the reflectance saturation and to the small spectral influence of soil background and plant stand shadowing on the simulated soybean canopy reflectance. When compared to the red interval (Figure 3b), directional and view angle effects were reduced in the NIR (Figure 3c) as well as in the SWIR (results not shown).

(a)

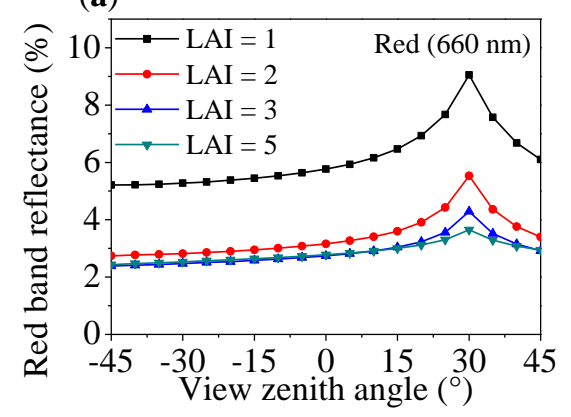

(b)

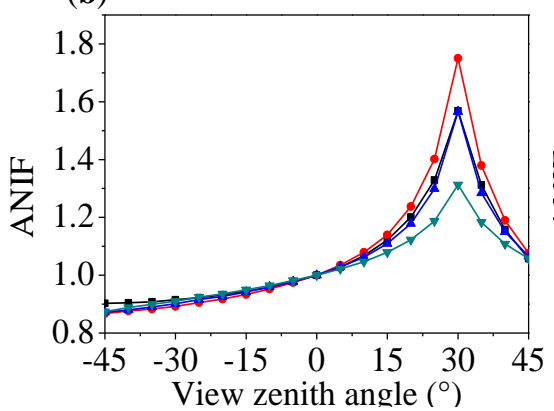

(c)

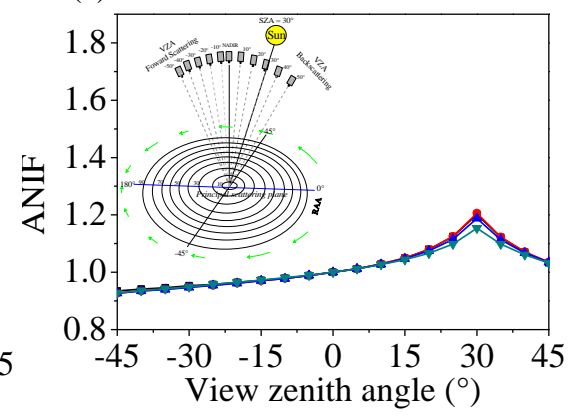

FIGURE 3. Directional and view zenith angle (VZA) effects, as a function of different LAI values, on the a) red reflectance $(660 \mathrm{~nm})$ of soybean; b) red anisotropic reflectance factor (ANIF); and c) NIR ANIF. SZA $\left(30^{\circ}\right)$, RAA $\left(0^{\circ}\right), \operatorname{LIDF}\left(13^{\circ}\right)$, chlorophyll $\left(30 \mu \mathrm{g} \cdot \mathrm{cm}^{-2}\right)$ and other parameters of Table 1 were kept fixed. 
Soybean has planophile canopy architecture with LIDF average values lower than $30^{\circ}$. The soybean LIDF is also dependent on its development stage. Changes in LIDF values usually result in reflectance variations and in different levels of dependence on viewing geometry. For example, when compared to the other crops with more erectophile canopy architecture (e.g., sugarcane); soybean is much more isotropic when reflecting radiation. An example is presented in Figure 4. For fixed LAI (value of 5) and chlorophyll concentrations, representing the beginning and full seed of soybean, view angle effects were stronger in the red (Figures $4 a$ and $4 b$ ) than in the NIR (Figure 4c) with increasing LIDF values, especially in the backscattering (positive VZA) and at the hot spot position. In fact, extreme LIDF values in Figure 4 represent the broad transition from planophile (e.g., soybean; $15^{\circ}$ ) to erectophile (e.g., sugarcane; $75^{\circ}$ ) canopy architectures rather than changes with soybean development.

(a)

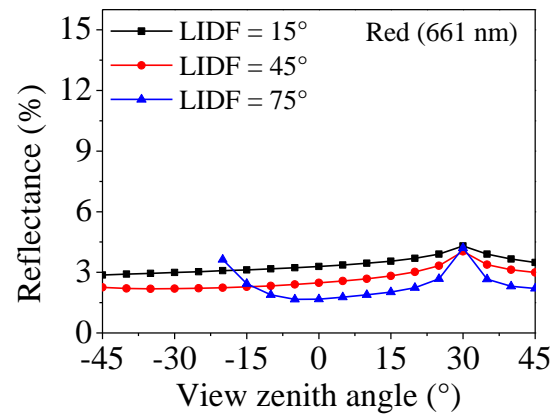

(b)

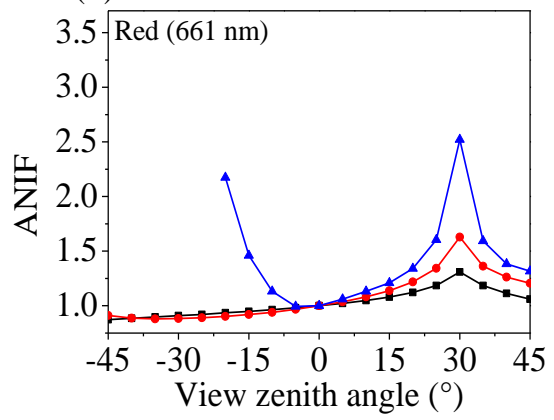

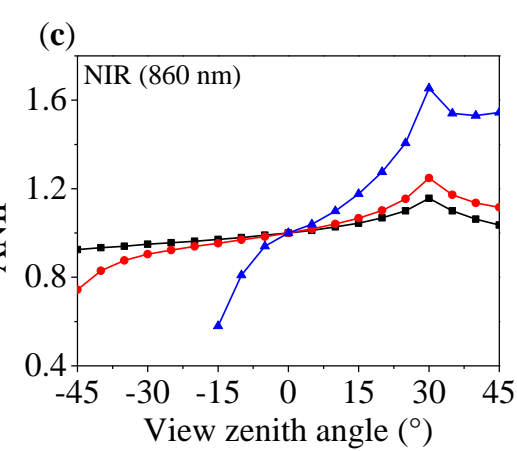

FIGURE 4. Directional and view zenith angle (VZA) effects, as a function of different LIDF values, on the a) red reflectance of soybean; b) red anisotropic reflectance factor (ANIF); and c) NIR ANIF. SZA $\left(30^{\circ}\right)$, RAA $\left(0^{\circ}\right)$, chlorophyll $\left(30 \mu \mathrm{g} . \mathrm{cm}^{-2}\right)$, LAI (5) and other parameters of Table 1 were kept fixed. Results for LIDF of $75^{\circ}$ were partially ommited to facilitate graphic representation.

\section{Variation in biochemical and biophysical parameters: the soybean vegetation index anisotropy from PROSAIL}

EVI displayed stronger anisotropic behavior than NDVI with view angle and view direction, especially in the hot spot (backscattering) and for a fixed LAI of 5 (Figures 5a and 5b). For NDVI, directional and view angle effects were stronger with decreasing chlorophyll concentrations from 50 to $10 \mu \mathrm{g} . \mathrm{cm}^{-2}$, but a reversal in EVI behavior was observed.

(a)

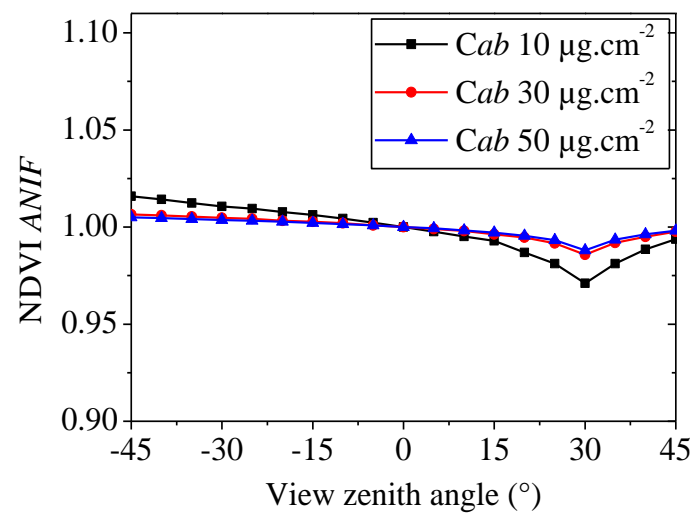

(b)

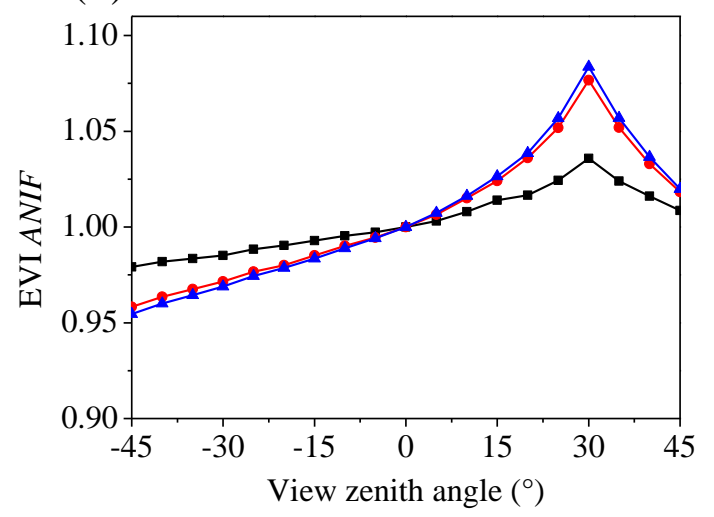

FIGURE 5. Directional and view zenith angle (VZA) effects, as a function of different chlorophyll concentrations of soybean, on the normalized-to-nadir a) NDVI; and b) EVI. SZA $\left(30^{\circ}\right)$, RAA $\left(0^{\circ}\right), \operatorname{LAI}(5), \operatorname{LIDF}\left(13^{\circ}\right)$ and other parameters of Table 1 were kept fixed. 
A reversal trend between NDVI and EVI was also noted when we fixed the chlorophyll concentration $\left(30 \mu \mathrm{g} \mathrm{cm}^{-2}\right)$ and varied the LAI values from 1 to 5 (Figures $6 \mathrm{a}$ and $6 \mathrm{~b}$ ). When compared to nadir viewing, much lower normalized NDVI values were observed in the backscattering with decreasing LAI values, but the contrary was verified for EVI, which presented much higher normalized values with canopy closure.

(a)

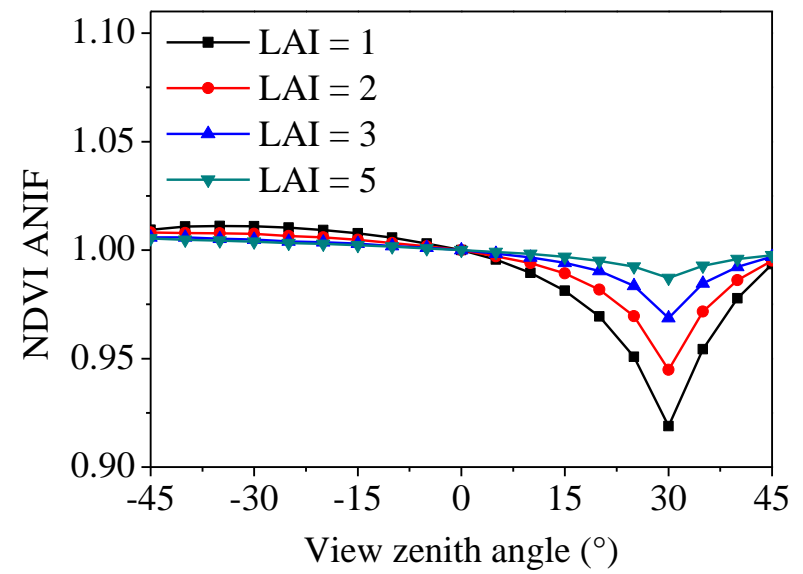

(b)

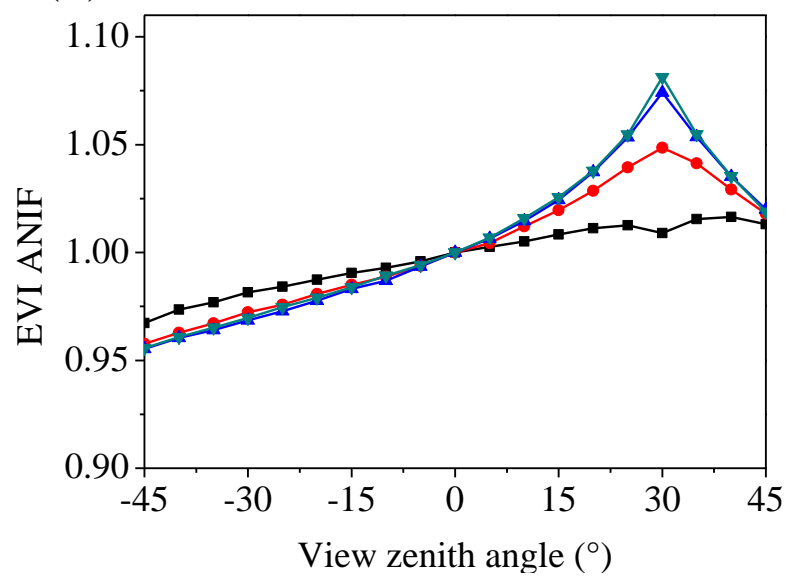

FIGURE 6. Directional and view zenith angle (VZA) effects, as a function of different LAI of soybean, on the normalized-to-nadir a) NDVI; and b) EVI. SZA $\left(30^{\circ}\right)$, RAA $\left(0^{\circ}\right)$, chlorophyll $\left(30 \mu \mathrm{g} \mathrm{cm}^{-2}\right)$, LIDF $\left(13^{\circ}\right)$ and other parameters of Table 1 were kept fixed.

\section{DISCUSSION}

View angle and directional effects on the visible, NIR and SWIR reflectance were stronger for incomplete soybean canopies (e.g., LAI $=2$ ) than for closed canopies (e.g., LAI $=5$ ). This result is in agreement with findings by EPIPHANIO \& HUETE (1995) and WALTER-SHEA et al. (1997) in field experiments performed with other crops. In the early plant development stage, the soil background is a significant source of reflectance variation due to the soil reflectance itself and to the plant stand shadowing on it (ROSENA et al., 1992; ZHAO et al., 2010). After canopy closure, the soil background influence is minimal and eventual angular effects on reflectance depend on crop row spacing, which is generally small $(45 \mathrm{~cm}$ ) for soybean (BREUNIG et al., 2011). The present study also showed that such effects were also reduced towards canopy closure with increasing chlorophyll concentration.

Depending on the vegetation index formulation, the combination of several bands can lead to a conflicting and misinterpretation of the data, since plant leaves absorb, reflect, and transmit light differentially across the whole spectrum (FITZGERALD et al., 2005). For example, NDVI presented higher values than EVI in the forward scattering. The opposite was verified in the backscattering. EVI was more sensitive to directional and view angle effects than NDVI, which is in agreement with recent studies by GALVÃO et al. (2011b) and SIMS et al. (2011) using MODIS and hyperspectral data. This fact can be associated to the greater dependence of EVI on the NIR reflectance (GALVÃO et al., 2011b) and to the fact that EVI uses two visible bands (blue and red), which are more affected by the geometry of data acquisition (LEBLON et al., 1996; APARICIO et al., 2004). As a result of its dependence on the NIR reflectance, EVI is much more sensitive to variations in LAI than NDVI but is also much more sensitive to view-illumination effects. On the other hand, NDVI is more dependent on the red reflectance variation (APARICIO et al., 2004) and tends to be comparatively more sensitive to pigment concentration than EVI.

Despite the quality improvement of satellite data mentioned by FENSHOLT et al. (2010), attention is necessary when using vegetation indices or daily reflectance images collected by large FOV sensors like MODIS due to canopy internal (geometry, leaf and soil optical properties) and external factors (view-illumination geometry and atmosphere) (APARICIO et al., 2004). View 
angle and directional effects on MODIS can produce erroneous interpretation of biophysical parameters, especially when radiative transfer modeling is replaced by empirical modeling due to the infrequent satellite observation resultant from cloud cover (BREUNIG et al., 2011). Viewing effects are also dependent on spectral mixtures of the scene components (FITZGERALD et al., 2005; SOMERS et al., 2011) and a validation stage is usually desirable to ensure the best representation of plant stand characteristics (WIDEN, 2004).

LIDF is important because, among other parameters, determines the extinction and scattering coefficients. For horizontally predominant leaves (planophile architecture), the extinction and bidirectional scattering coefficients tend to be constant. In plant stands with vertically predominant leaves (erectophile architecture), the extinction coefficient increases according to the tangent of the observation angle (monotonous increases) and the bidirectional scattering coefficient assumes a "V" shape centered at nadir position (VERHOEF, 1984). PROSAIL results showed that soybean canopies with lower LIDF values are more isotropic than other canopies with erectophile canopy architecture (higher LIDF values). However, view angle and directional effects were still present over soybean canopies and even on real Hyperion and MODIS data collected over soybean farms in the Mato Grosso State (GALVÃO et al., 2009; BREUNIG et al., 2011).

\section{CONCLUSIONS}

Results showed good agreement between simulated and satellite reflectance spectra (MODIS and Hyperion) that confirmed the ability of PROSAIL to model soybean spectral response under different biochemical and biophysical attributes, and viewing geometry. View angle and directional effects on the visible, NIR and SWIR reflectance were stronger for incomplete soybean canopies than for closed canopies or for increasing chlorophyll concentration. They were evident in the backscattering (positive VZA) due to the predominance of sunlit canopy components towards sensor, especially at the hot spot geometry (VZA and SZA $=30^{\circ}$ ). Analysis of LIDF values anticipates the conclusion that soybean (planophile canopy architecture) is more isotropic than other crops with more erectophile canopy architecture (e.g., sugarcane with higher LIDF values).

When compared to NDVI, EVI was much more sensitive to viewing geometry having larger values in the backscattering (hot spot). The inverse was observed for NDVI that presented higher values in the forward scattering direction. Differences in the response of the two indices with viewing geometry are due to the greater dependence of EVI on the NIR reflectance, which had also more anisotropic behavior for closed canopies.

Results emphasized that care is necessary when analyzing daily images collected by large FOV sensors. Because the soybean development in central Brazil is coincident with the peak of cloud cover season, even the analysis of 8- or 16-days MODIS composite images should consider information associated to pixel quality, including the view zenith angle and direction of the pixels selected to be included into the composite product.

\section{ACKNOWLEDGEMENTS}

The authors are very grateful to Grupo André Maggi for providing agronomic information for the project and to the anonymous reviewers for the useful suggestions. Thanks are also due to FAPESP (Fundação de Amparo à Pesquisa do Estado de São Paulo; grant number 2008/11499-8), CNPq (Conselho Nacional de Desenvolvimento Científico e Tecnológico), and to CAPES (Coordenação de Aperfeiçoamento de Pessoal de Nível Superior).

\section{REFERENCES}

APARICIO, N.; VILLEGAS, D.; ROYO, C.; CASADESUS, J.; ARAUS, J. L. Effect of sensor view angle on the assessment of agronomic traits by ground level hyper-spectral reflectance measurements in durum wheat under contrasting Mediterranean conditions. International Journal of Remote Sensing, London, v.25, n.6, p.1131-52, Mar. 2004. 
ARAUJO, G. K. D.; ROCHA, J. V.; LAMPARELLI, R. A. C.; ROCHA, A. M.. Mapping of summer crops in the State of Paraná, Brazil, through the 10-day spot vegetation NDVI composites. Engenharia Agrícola, Jaboticabal, v.31, n.4, p.760-770, mar/abr. 2011.

ATZBERGER, C. Inverting the PROSAIL canopy reflectance model using neural nets trained on streamlined databases. Journal of Spectral Imaging, Chichester, v.1, n.a2, p.1-13, nov. 2010.

BREUNIG, F. M.; GALVÃO, L. S.; FORMAGGIO, A. R.; EPIPHANIO, J. C. N. Directional effects on NDVI and LAI retrievals from MODIS: A case study in Brazil with soybean.

International Journal of Applied Earth Observation and Geoinformation, Amsterdam, v.13, n.1, p.34-42, feb. 2011.

EPIPHANIO, J. C. N.; HUETE, A. R. Dependence of NDVI and SAVI on sun/sensor geometry and its effect on fAPAR relationships in Alfalfa. Remote Sensing of Environment, Amsterdam, v.51, n.3, p.351-360, mar. 1995.

FANG, H. L.; LIANG, S. L.; HOOGENBOOM, G.; TEASDALE, J.; CAVIGELLI, M. Corn-yield estimation through assimilation of remotely sensed data into the CSM- CERES- Maize model. International Journal of Remote Sensing, London, v.29, n.10, p.3011-3032, may 2008.

FENSHOLT, R.; SANDHOLT, I.; PROUD, S.; STISEN, S.; RASMUSSEN, M. O. Assessment of MODIS sun-sensor geometry variations effect on observed NDVI using MSG SEVIRI geostationary data. International Journal of Remote Sensing, London, v.31, n.23, p.6163-6187, dec. 2010.

FÉRET, J. B.; FRANÇOIS, C.; ASNER, G. P.; GITELSON, A. A.; MARTIN, R. E.; BIDEL, L.P.R.; USTIN, S. L.; LE MAIRE, G.; JACQUEMOUD, S. PROSPECT-4 and 5: advances in the leaf optical properties model separating photosynthetic pigments. Remote Sensing of Environment, Amsterdam, v.112, n.6, p.3030-3043, jun. 2008.

FITZGERALD, G.; PINTER Jr., P.; HUNSAKER, D.; CLARKE, T. Multiple shadow fractions in spectral mixture analysis of a cotton canopy. Remote Sensing of Environment, Amsterdam, v.97, n.4, p.526-539, sep. 2005.

FRITSCHI, F. B.; RAY, J. D. Soybean leaf nitrogen, chlorophyll content, and chlorophyll a/b ratio. Photosynthetica, Berlin, v.45, n.1, p.92-98, 2007.

GALVÃO, L. S.; ROBERTS, D. A.; FORMAGGIO, A. R.; NUMATA, I.; BREUNIG, F. M. View angle effects on the discrimination of soybean varieties and on the relationships between vegetation indices and yield using off-nadir Hyperion data. Remote Sensing of Environment, Amsterdam, v.113, n.4, p.846-856, apr. 2009.

GALVÃO, L. S.; EPIPHANIO, J. C. N.; BREUNIG, F. M.; FORMAGGIO, A.R. Crop type discrimination using hyperspectral data. In: THENKABAIL, P. S.; LYON, J. G.; HUETE, A. (Ed.). Hyperspectral remote sensing of vegetation. Boca Raton: CRC Press, 2011a. chapter 17, p. 397421.

GALVÃO, L. S.; SANTOS, J. R. dos; ROBERTS, D. A.; BREUNIG, F. M.; TOOMEY, M.; MOURA, Y. M. On intra-annual EVI variability in the dry season of tropical forest: A case study with MODIS and hyperspectral data. Remote Sensing of Environment, Amsterdam, v.115, n.9, p.2350-2359, sep. 2011b.

JACQUEMOUD, S. Inversion of the PROSPECT + SAIL canopy reflectance model from AVIRIS equivalent spectra: Theoretical study. Remote Sensing of Environment, Amsterdam, v.44, n.2-3, p.281-292, may 1993.

JACQUEMOUD, S.; VERHOEF, W.; BARET, F.; BACOUR, C.; ZARCO-TEJADA, P. J.; ASNER, G. P.; FRANÇOIS, C.; USTIN, S. L. PROSPECT+SAIL models: A review of use for vegetation characterization. Remote Sensing of Environment, Amsterdam, v.113, n. suppl. 1, p.S56S66, sep. 2009. 
LEBLON, B.; GALLANT, L.; GRANBERG, H. Effects of shadowing types on ground-measured visible and near-infrared shadow reflectances. Remote Sensing of Environment, Amsterdam, v.58, n.3, p.322-328, Dec. 1996.

MARSDEN, C.; MAIRE, G.; STAPE, J.; SEEN, D. L.; ROUPSARD, O.; CABRAL, O.; EPRON, D.; LIMA, A. M. N.; NOUVELLON, Y. Relating MODIS vegetation index time-series with structure, light absorption and stem production of fast-growing Eucalyptus plantations. Forest Ecology and Management, Amsterdam, v.259, n.9, p.1741-1753, Apr. 2010.

RIZZI, R.; RUDORFF, B. F. T. MODIS sensor images associated with an agronomic model to estimate soybean grain yield. Pesquisa Agropecuária Brasileira, Brasília, v.42, n.1, p.73-80, jan. 2007.

RODRIGUEZ, J. O.; ANDRADE, E. M.; TEIXEIRA, A. S.; SILVA, B. B. Sazonalidade de variáveis biofísicas em regiões semiáridas pelo emprego do sensoriamento remoto. Engenharia Agrícola, Jaboticabal, v.29, n.3, p.452-465, jul./set. 2009.

ROSENA, A.; VERHOEF, W.; NOORBERGEN, H.; BORGESIUS, J. J. A new forest light interaction model in support of forest monitoring. Remote Sensing of Environment, Amsterdam, v.41, n.1, p. 23-41, Oct. 1992.

SANDMEIER, S. R.; ITTEN, K. I. A field goniometer system (FIGOS) for acquisition of hyperspectral BRDF data. IEEE Transactions on Geoscience and Remote Sensing, New York, v.37, n.2, p.978-986, mar. 1999.

SIMS, D. A.; RAHMAN, A. F.; VERMOTE, E. F.; JIANG, Z. N. Seasonal and inter-annual variation in view angle effects on MODIS vegetation indices at three forest sites. Remote Sensing of Environment, Amsterdam, v.115, n.12, p.3112-3120, Jul. 2011.

SOLANO, R.; DIDAN, K.; JACOBSON, A.; HUETE, A. MODIS vegetation indices (MOD13) C5: user's guide. Tucson: The University of Arizona, 2010. 38 p.

SOMERS, B.; ASNER, G. P.; TITS, L.; COPPIN, P. Endmember variability in Spectral Mixture Analysis: A review. Remote Sensing of Environment, Amsterdam, v.115, n.7, p.1603-1616, jul. 2011.

THE MATHWORKS INC. MATLAB®: The language of Technical Computing. Natick, Massachusetts: The Math Works, 2008.

VERHOEF, W. Light scattering by leaf layers with application to canopy reflectance modeling: The SAIL model. Remote Sensing of Environment, Amsterdam, v.16, n.2, p.125-141, oct. 1984.

VERHOEF, W.; LI, J.; QING, X.; SU, Z. Unified optical-thermal four-stream radiative transfer theory for homogeneous vegetation canopies. IEEE Transactions on Geoscience and Remote Sensing, New York, v.45, n.6, p.1808-1822, jun. 2007.

WALTER-SHEA, E. A.; PRIVETTE, J.; CORNELL, D.; MESARCH, M. A.; HAYS, C. J. Relations between directional spectral vegetation indices and leaf area and absorbed radiation in alfalfa. Remote Sensing of Environment, Amsterdam, v.61, n.1, p.162-177, jul. 1997.

WANG, L.; HUNT, J.; QU, J. J.; HAO, X.; DAUGHTRY, C. S. T. Towards estimation of canopy foliar biomass with spectral reflectance measurements. Remote Sensing of Environment, Amsterdam, v.115, n.3, p.836-840, mar. 2011.

WARDLOW, B. D.; EGBERT, S. L. Large-area crop mapping using time-series MODIS $250 \mathrm{~m}$ NDVI data: An assessment for the U.S. Central Great Plains. Remote Sensing of Environment, Amsterdam, v.112, n.3, p.1096-1116, mar. 2008.

WIDEN, N. Assessing the accuracy of land surface characteristics estimated from multi-angular remotely sensed data. International Journal of Remote Sensing, London, v.25, n.6, p.1105-1117, mar. 2004. 
XIONG, X.; CHIANG, K.; SUN, J.; BARNES, W.; GUENTHER, B.; SALOMONSON, V. NASA EOS Terra and Aqua MODIS on-orbit performance. Advances in Space Research, Amsterdam, v.43, n.3, p.413-422, feb. 2009.

ZHAO, F.; GU, X.; VERHOEF, W.; WANG, Q.; YU, T.; LIU, Q.; HUANG, H.; QIN, W.; CHEN, L.; ZHAO, H. A spectral directional reflectance model of row crops. Remote Sensing of Environment, Amsterdam, v.114, n.2, p.265-285, feb. 2010. 